problems, and deafness, ${ }^{910}$ as well as sudden infant death. ${ }^{112}$

The task of clearing the population of potentially dangerous viruses before immunisation may well prove impossible; but does that justify our setting up ill-founded contraindications, rather than real ones, and then shooting them down in order to prove that our vaccines are safe?

P E BROWN JOHN E LUNN

Department of Community Medicine,

Shiversity of Sheffield 10 R

${ }^{1}$ Köng E von. Helvet, Pediat, Acta 1953;8:90-8.

${ }_{3}^{2}$ Halpern SR, Halpern D. $\mathcal{F}$ Pediatr 195

4 Anonymous. F Ann N Y Acad Sci 1974;221:324-30

Baird HW, Berefsky LG. F Pediatr 1957;50:332-9.

Feldman RA, Schwarz JF. Lancet 1968;i:180-1.

Pittman M. In: Mudd S, ed. Infectious agents and host reactions. Philadelphia: W D Saunders, 1970: 239-70.

${ }^{8}$ Elek SD, Stern H. Lancet $1974 ;$ i :1-5.

Hanshaw JB, Scheiner AP, Moxley AW, Gaev L Abel V, Scheiner B. N Engl f Med 1976;295:

10 Melish $M$

$190-4$.

11 Potencz H, Diosi P. F Pediatr 1974;85:281-3.
12 Nazarov V. Sud Med Ekspert $1978 ; \mathbf{2 1}(4): 31-3$.

SIR,-In answer to Professor R S Illingworth's letter (19 January, p 179) about the multitude of curious reasons given for not allowing children to be immunised against whooping cough, I would suggest the following.

Mothers have just undergone nine months of bodily change of varying discomfort followed by a less comfortable, and perhaps dangerous, process at the end of it, in most cases to produce (one hopes) a wanted child. Not only are they then asked to submit that child to a possibly damaging procedure (the risks of which have been quantified differently by different authorities) but they are asked at a time when they may be suffering from mild postnatal depression; and, as anyone who has ever felt depressed knows, this is not a time when one can confidently and rationally take a decision.

Sometimes fathers can help by giving a firm lead, but often the mother looks to the health visitor or doctor to decide for hersomething which is debatably not justifiable in the circumstances. She is frequently happier if the immuniser misses out the whooping-cough vaccine and afterwards she may present as reason for this any unusual fact in the child's family or medical history. The medical adviser may consciously or unconsciously have considered this, but in fact he or she is attempting to respond correctly to the mother's doubts and fears, while also acting in the interests of the child to protect it by immunisation against othe diseases - at the very least polio only, which involves no "jab."

I sometimes consider postnatal depression sufficient of an argument to start immunisation at six months, not earlier. This is consisten with immunology, although other factors may sway policy towards an earlier start.

M C ROBERTSON

Swindon, Wilts

Mortality of male doctors and reductions in cigarette smoking

SIR,-We disagree with Mr P N Lee's analysis of the mortality of male doctors (15 December, p 1538) and his provocative conclusion that the benefits of giving up smoking may not be so great as has commonly been assumed. His calculations, which are obtained by a complex manipulation of standardised mortality ratios, showed "savings" in deaths from three major cigarette related diseases: coronary heart disease (83 deaths saved), stroke (16), and lung cancer (8). These savings are compared with "losses" from three stress-related conditions: accidents, poisonings, etc (30), suicide (26) and cirrhosis of liver (4). The implication is made that the doctors have become more prone to these stressful conditions partly owing to a possible adverse effect of giving up smoking. The analysis is based on the Registrar General's occupational mortality tables for England and Wales, which restrict attention to men under 65 years of age.

Life certainly does not end at 65 years; in England and Wales the expectation of life for men at 65 is 12 years and the doctors can expect to live even longer. It is therefore of vital interest to have an overall analysis of "savings" and "losses" in deaths over the whole life span of the doctors. Unfortunately national data are not available for this task; the answers on the extent of benefits arising from giving up smoking for the particular group of British doctors lie with the follow-up study of Doll et al. ${ }^{12}$

The national figures for male deaths attributed to these cigarette-related diseases (table) show that a large majority of deaths occur in the postretirment age group. ${ }^{3}$ In contrast, the number of deaths from the stress-related conditions thought to be partly attributable to giving up smoking largely occur in the working age group. These opposing trends clearly demonstrate that the "savings" would rise and the "losses" diminish in the postretirement age. In this context we cannot understand why $\mathrm{Mr}$ Lee believes that the effect of giving up smoking might be seen most clearly in the younger age groups. It is most unlikely that these trends observed in the general population would be markedly different in the doctors. Ninety per cent of lung cancer deaths occur among smokers. ${ }^{4}$ It is estimated that in England and Wales the number of lung cancer deaths that could be saved by giving up smoking (22 000 lives) far outnumber the total number of stress-related conditions (12 383) that could partly be attributable to giving up smoking. These estimates are based on the assumption that $50 \%$ of adult males smoke cigarettes. ${ }^{5}$

Sixty-three per cent of ischaemic heart disease deaths occur among smokers; the number of lives saved annually is expected to be over 23000 . We firmly believe that the number of lives saved by giving up smoking will far outweigh the lives lost by the adverse effect of stress-related conditions arising

Number of deaths in smoking-related and stress-related conditions in two broad age groups for men (England and Wales 1977)

\begin{tabular}{|c|c|c|c|c|c|}
\hline & & \multirow{2}{*}{$\begin{array}{l}\text { Number } \\
\text { of deaths }\end{array}$} & \multicolumn{2}{|c|}{ Age } & \multirow{2}{*}{$\begin{array}{c}\text { Ratio of deaths } \\
\frac{25 y}{<65 y}\end{array}$} \\
\hline & & & $<65 \mathrm{y}$ & $\geqslant 65 \mathrm{y}$ & \\
\hline \multirow[t]{2}{*}{$\begin{array}{l}\text { Cigarette-related } \\
\text { conditions }\end{array}$} & $\begin{array}{l}\text { Ischaemic heart disease } \\
\text { Lung cancer } \\
\text { Cerebrovascular disease }\end{array}$ & $\begin{array}{l}89411 \\
26679 \\
27831\end{array}$ & $\begin{array}{r}28613 \\
9193 \\
4896\end{array}$ & $\begin{array}{l}60798 \\
17486 \\
22935\end{array}$ & $\begin{array}{l}2 \cdot 12 \\
1 \cdot 90 \\
4 \cdot 68\end{array}$ \\
\hline & Subtotal & 143921 & 42702 & 101219 & $2 \cdot 37$ \\
\hline \multirow[t]{2}{*}{$\begin{array}{l}\text { Stress-related } \\
\text { conditions }\end{array}$} & $\begin{array}{l}\text { Accidents, poisonings, etc } \\
\text { Suicide } \\
\text { Cirrhosis of liver }\end{array}$ & $\begin{array}{r}9029 \\
2363 \\
991\end{array}$ & $\begin{array}{r}6691 \\
1851 \\
640 \\
\end{array}$ & $\begin{array}{r}2338 \\
512 \\
351 \\
\end{array}$ & $\begin{array}{l}0.35 \\
0.28 \\
0.55\end{array}$ \\
\hline & Subtotal & 12383 & 9182 & 3201 & 0.35 \\
\hline
\end{tabular}

from giving up if all age groups are included in the analysis of male doctors.

Mr Lee's restricted analysis up to retiring age showing a small gain of $5 \%$ in lives saved by the reduction of smoking in doctors is misleading and can seriously affect the preventive programmes on smoking. There might be a small percentage of smokers who would be better off smoking than giving up but it is for the smoker himself to weigh up the relative advantages and disadvantages. For the large majority of smokers, however, it is prudent to give up rather than to continue. We believe that this overall conclusion is true for every subgroup of the population, including the doctors.

T KHOSLA

H CAMPBELL

Department of Medical Statistics,

Welsh National School of Medicine,

1 Doll R, and Hill AB. Br Med F $1954 ;$; :1451-5.

2 Doll R, and Peto R. Br Med $\mathcal{F} 1976 ;$;ii:1525-36.

Office of Population Censuses and Surveys. Mortality
statistics (cause). Series DH2, No 4, London: statistics (cause)

"Khosla T. Health Educ f 1979;38:58-62.

Royal College of Physicians. Smoking or health.

SIR,-The conclusion by Mr P N Lee (15 December, $p$ 1584) that the tar reduction in cigarettes occurred before publication of the first tar table in 1973 and that the table was "on the industry's own initiative" deserves comment.

The first publication of tar and nicotine retrieval from cigarettes identified by brand was in $1967 .{ }^{1}$ This article was published despite the opposition of tobacco interests, some governmental groups, and even several fellow scientists who deplored its practical message. Shortly after this publication and the subsequent listings by the Federal Trade Comnicotine levels as part of their advertisements.

GEORGE E MOORE

Division of Surgical Oncology,

Department of Health and Hospitals

${ }^{1}$ Moore GE, Bross I, Shamberger R, Bock FG. Cancer $967 \cdot 20 \cdot 323-32$.

\section{Prophylaxis against postoperative pulmonary embolism}

SIR,-The comprehensive study by Dr U F Gruber and others (12 January, p 69) on the prevention of fatal pulmonary embolus will interest all pelvic surgeons. Two deaths followed 414 gynaecological operations (all in women over 40 years and lasting more than 30 minutes). One was after dextran and the mission industry began to publish tar and 